\title{
A Minimalist-Based Approach to Phrasal Verb Movement in North Hail Arabic
}

\author{
Murdhy Radad Alshamari ${ }^{1} \&$ Marwan Jarrah ${ }^{2}$ \\ ${ }^{1}$ University of Hail, Hail, Kingdom of Saudi Arabia and Newcastle University, Newcastle upon Tyne, UK \\ ${ }^{2}$ University of Jordan, Amman, Jordan and Newcastle University, Newcastle upon Tyne, UK \\ Correspondence: Murdhy R. Alshamari, School of English Literature, Language and Linguistics, Newcastle \\ University, Newcastle, 5 Lonsdale Court, West Jesmond Avenue NE23HF, Newcastle Upon Tyne, Tyne and Wear, \\ UK. Tel: 44-74-7990-9091. E-mail: snxparticles@yahoo.com
}

Received: November 19, 2015 Accepted: December 30, 2015 Online Published: January 31, 2016

doi:10.5539/ijel.v6n1p24

URL: http://dx.doi.org/10.5539/ijel.v6n1p24

\begin{abstract}
This research explores one less-investigated though significant manifestation of verb movement in North Hail Arabic, namely verb topicalization alongside its internal argument and any accompanying adjunct. In adequate dialogical and pragmatic contexts, the lexical verb (L-verb), the direct object (DO), and VP and vP adjoining adjuncts appear to move to the Specifier position (Spec) of a dedicated Topic Phrase in the left periphery in the sense of Rizzi (1997). This quasi-holistic movement is labelled as Defective Predicate Topicalization (DPT), where all predicate elements, apart from Tense, move overtly to Topic Phrase. Linear order between the L-verb, the DO, and any accompanying adjuncts is assumed, among others, to be evidence supporting this contention. Furthermore, the study argues that DPT is syntactically licensed for its phrasal-movement fashion. Hence, no violation of (head-related) locality principles is involved.
\end{abstract}

Keywords: verb movement, topicalization, locality, intervention

\section{Introduction}

Following the recent debate in cross-linguistic syntax regarding verb movement and topicalization (cf. Truckenbrodt, 2006; Roberts, 2007; Biberauer et al., 2009; Bentzen, 2014), the current research delves into verb topicalization in North Hail Arabic (henceforth, NHA), an Arabic variety spoken in Saudi Arabia. It basically examines how this discourse-invoked movement is syntactically derived and hence construed. No consensus even partial has been hitherto reached among researchers on the precise character of verb movement (see, e.g., Koeneman, 2000; Roberts, 2005; Haeberli \& Pintzuk, 2012), an issue taken as motivation for the current research.

As for Arabic, it has been widely suggested that this language exhibits less restrictions on possible word orders, even in discourse-neutral cases (cf. Ouhalla, 1994; Bolotin, 1995; Tucker, 2011; Ackema \& Neeleman, 2012). Such a state of affairs has been a major source for a lot of insightful controversies (Kenstowicz, 1989; Shlonsky, 1997; Ouhalla \& Shlonsky, 2002; Saiegh-Haddad \& Henkin-Roitfarb, 2014). Verb positions as well as movement in Arabic have been worth exploring for the complexities they induce for a possible unified account of Arabic clause structure. This exploration is reinforced and sounds rather necessary as far as NHA is concerned. Few studies have tackled this variety despite the fact that it exhibits several unique structures not all exhibited in related dialects or Modern Standard Arabic. The recent studies on this Arabic dialect have been limited to some aspects of grammar rather than syntax (cf. Alshamari, 2015a, b, c and Alrasheedi, 2015). This being the case, the current research is of importance for two interrelated aspects. It is firstly a humble continuation of the ongoing debate on verb movement and topicalization in natural languages. Secondly, it addresses NHA, whose clause structure and verb movement have never come under scrutiny.

The following discussion is organized as follows. Section 2 sets out the scene, introducing the main descriptive facts that hold for verb topicalization in NHA, coupled with preliminary analysis to the basic observations. Section 3 includes the main analysis and discussion. It argues that verb topicalization in NHA undergoes phrasal movement instead of the apparent head movement. Facts drawn on adjuncts, DO position and movement, and overt tense are all taken as evidence for this thesis. Section 4 concludes the research with some pointers to 
further research.

\section{Descriptive Facts and Preliminary Analysis}

In order to examine our main hypothesis that NHA maintains verb topicalization, let us explore examples where $\mathrm{T}^{\mathrm{o}}$ is overt. Under such cases it is less challenging to detect verb movement (cf. Fassi Fehri, 2012). What basically makes verb-phrase movement in Arabic varieties less clear to determine is that the tense affix, borrowing Chomsky's (1995) metaphor, is strong and thus need be either overt or adjoined to an appropriate host (cf. Radford, 1997, 2009; Biberauer \& Roberts, 2007). In most cases, the lexical verb (L-verb) serves as the host after movement to $\mathrm{T}^{\mathrm{o}}$ in overt syntax. From this point onwards, any further L-verb movement to the left periphery is taken to be tense movement rather than L-verb or L-verb-phrase movement. On the other hand, when tense is overt (i.e., lexically materialized), L-verb movement either at the zero level or at the XP level becomes less obscure and, presumably, easy to capture (cf. Kremers, 2012).

This path of analysis demands the tested sentences to be in the past and, in most cases, denote progressive aspect. It is a priori reasoning since under such cases $\mathrm{T}^{\mathrm{o}}$ is overtly filled by kaan (be.past) (see, e.g., Aoun et al., 2010; Owens, 2013). Consider the following examples:

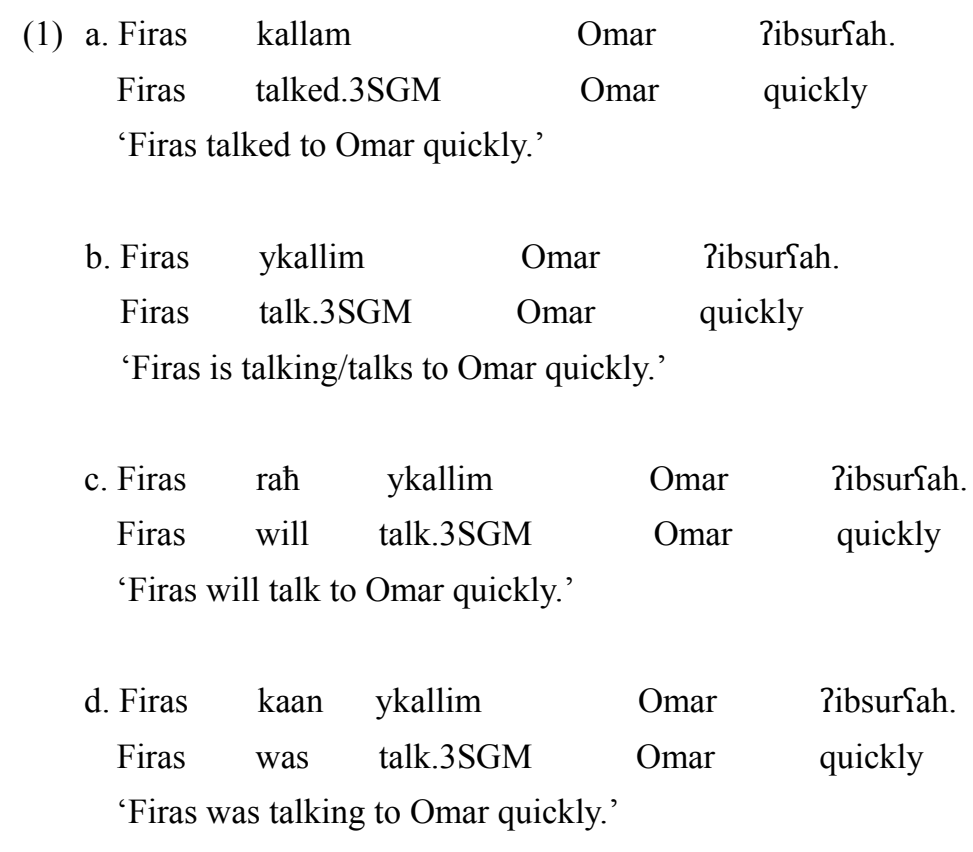

In (1a), L-verb kallam 'talked' is in the past, displaying simple aspect; hence, tense is null. It is commonly viewed that the tense affix [PAST] is nonconcatenatively fused with L-verb, yielding the 'past' reading (see, Fassi Fehri, 1993(2013)). In (1b), L-verb ykallim appears in present form, yielding both simple and progressive readings. In either case, the tense affix is null. In (1c), the event is in the future by virtue of the modal future

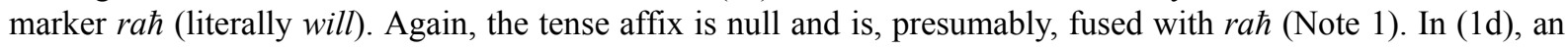
overt form of tense is used, namely kaan due to the fact that the sentence bears a progressive past tense reading. Some evidence for the assumption that kaan is an overt tense filler comes directly from its behavior vis-à-vis temporal adverbs. Both present and future adverbs are incompatible with this temporal filler. For instance, if the manner adverb Ribsur Sah 'quickly' in (1d) is replaced by Palhi:n 'right now' or bukra 'tomorrow', the resulting sentence becomes infelicitous being a semantic anomaly.
(2) a. Firas
kaan
ykallim
Omar
*?alhi:n/*bukra.
Firas
was talk.3SGM
Omar
right now/ tomorrow

Incompatibility of kaan with either Palhi:n 'right now' or bukra 'tomorrow' is resulted from tense clash, i.e., tense is in the past, whereas adverbs are present and future, respectively (Note 2). Additionally, the status of kaan, as an overt realization of tense, has been widely assumed in many relevant studies that address the tense system 
in Arabic (e.g., Kinberg, 1992; Benmamoun, 1999, 2000; Fassi Fehri, 1993 (2013), 2012). Cruical here is that sentence (1d) represents the unmarked order of the subject, tense, L-verb, and the DO. Unmarkedness is, in broad terms, utilized in context-free cases, where discourse plays no role for sentence derivation and interpretation (cf. Lambrecht, 1996; Soricut \& Marcu, 2003).

Against this background and following current generative framework on structure of natural languages in general and Arabic in particular (cf. Aoun et al., 2010), the subject, Firas, in (1d), reproduced below for convenience, occupies SpecTP though it generates in SpecvP. kaan is canonically in $\mathrm{T}^{\circ}$, while L-verb ykallim 'talk' adjoins little $\mathrm{v}$ heading $\mathrm{vP}$.
(3) Firas
kaan ykallim
Omar
Ribsurfah.
Firas
was talk.3SGM
Omar
quickly

'Firas was talking to Omar quickly.'

Under such cases, the DO shows up to the right of L-verb followed, in turn, by adjuncts, if any. As seen from (3), L-verb ykallim 'talk' is free of any tense-bound reading. What furnishes the given sentence with 'past reading' is kaan rather than ykallim 'talk'. This implies that L-verb does not adjoin $\mathrm{T}^{\circ}$ being overtly filled by kaan. An intuitive conclusion thus far is that L-verb movement to $\mathrm{T}^{\circ}$ in overt syntax is restricted in the sense that $\mathrm{T}^{\circ}$ demands it or not. Put another way, L-verb movement is not self-driven but forced independently by morphological needs of $\mathrm{T}^{\mathrm{o}}$ (see, Bobaljik, 2000; Koeneman \& Zeijlstra, 2014). Using the Minimalist terms, L-verb movement to $T^{o}$ is not triggered by Greed but rather self-enlightened (see Lasnik, 1995). Some prima facie evidence for the assumption that L-verb in (3) above does not adjoin $\mathrm{T}^{\mathrm{o}}$ follows from scrambling of the manner adverb Ribsur Sah 'quickly' to a position intervening between kaan and L-verb ykallim 'talk'. Consider the following sentence:

$\begin{array}{lllll}\text { (4) Firas } & \text { kaan } & \text { Tibsurfah } & \text { ykallim } & \text { Omar. } \\ \text { Firas } & \text { was } & \text { quickly } & \text { talk.3SGM } & \text { Omar }\end{array}$

'Firas was talking to Omar quickly.'

L-verb ykallim 'talk' remains below (immediately following) the VP-adverb Ribsur Yah 'quickly' that intervenes between kaan and L-verb per se. Furthermore, the possible position of the subject between L-verb ykallim 'talk' and $\mathrm{T}^{\mathrm{o}}$ is taken as another clue that $\mathrm{L}$-verb does not adjoin $\mathrm{T}^{\mathrm{o}}$ while the latter is overtly filled. Consider (5).

$\begin{array}{lllll}\text { (5) kaan } & \text { Firas } & \text { ykallim } & \text { Omar } & \text { Pibsurfah. } \\ \text { was } & \text { Firas } & \text { talk.3SGM } & \text { Omar } & \text { quickly }\end{array}$

'Firas was talking to Omar quickly.'

As such, it is quite evident that the position the subject Firas occupies underlies that L-verb ykallim 'talk' is not adjoined to $\mathrm{T}^{\mathrm{o}}$ but rather positioned in a (lower) position. Both facts (scrambling of manner adverbs and the subject position in relation to $\mathrm{T}^{\circ}$ and L-verb) can be interestingly combined in one single clause, as in (6) below:

$\begin{array}{lllll}\text { (6) kaan } & \text { Firas } & \text { ?ibsurfah } & \text { ykallim } & \text { Omar. } \\ \text { was } & \text { Firas } & \text { quickly } & \text { talk.3SGM } & \text { Omar }\end{array}$

'Firas was talking to Omar quickly.'

These facts militate altogether against the assumption that L-verb and $\mathrm{T}^{\mathrm{o}}$ are, informally speaking, in the same position within the hierarchal structure of the given sentence. kaan occupies a position (i.e., $\mathrm{T}^{\circ}$ ) different from that of L-verb. At this point, the discussion of L-verb movement to the left periphery becomes relevant. Under an appropriate context, L-verb in NHA can move to some other position in the left of $\mathrm{T}^{\mathrm{o}}$, provided that the DO is 
pied-piped along with it. Consider the following examples:

$\begin{array}{lccr}\text { (7) a. ykallim } & \text { Omar } & \text { Firas } & \text { kaan. } \\ \text { talk.3SGM } & \text { Omar } & \text { Firas } & \text { was } \\ \text { 'Talking to Omar, Firas was.' } & \\ & & & \\ \text { b. *ykallim } & \text { Firas } & \text { kaan } & \text { Omar. } \\ \text { talk.3SGM } & \text { Firas } & \text { was } & \text { Omar }\end{array}$

Intended: 'Talking to Omar, Firas was.'

In (7a), the DO Omar is dragged all along with L-verb ykallim, while it remains in situ in (7b), whence the ungrammaticality of the latter. On the other hand, the DO can leave its position to the left periphery without demanding the L-verb to move along, or, standardly speaking, get pied-piped.

$\begin{array}{llll}\text { (8) Omar } & \text { Firas } & \text { kaan } & \text { ykallim-uh. } \\ \text { Omar } & \text { Firas } & \text { was } & \text { talk.3SGM-3SGM }\end{array}$

'Omar, Firas was talking to him.'

(8) implies that although the DO Omar moves separately to the left periphery without an accompanying movement of L-verb ykallim, the sentence holds grammatical. The moved DO Omar incurs a resumptive clitic on L-verb ykallim, as a must, if topicalization reading is intended for the DO (cf. Schub, 1977; Shlonsky, 1997; Lewis, 2013). That said, it can be postulated that L-verb fronting is more restricted than DO fronting. If L-verb gets fronted, the DO must be carried along; otherwise, the sentence becomes ungrammatical. The same analogy is not extended though to DO fronting which does not force L-verb fronting.

When L-verb and the DO get fronted, the former must precede the latter; otherwise, the sentence is ungrammatical under the reading that the word preceding L-verb is the DO:

(9)

$\begin{array}{llll}\text { *Omar } & \text { ykallim } & \text { Firas kaan. } \\ \text { Omar } & \text { talk.3SGM } & \text { Firas was }\end{array}$

The last issue to highlight before winding up this section is that any accompanying adjunct must move along L-verb if the latter gets fronted:

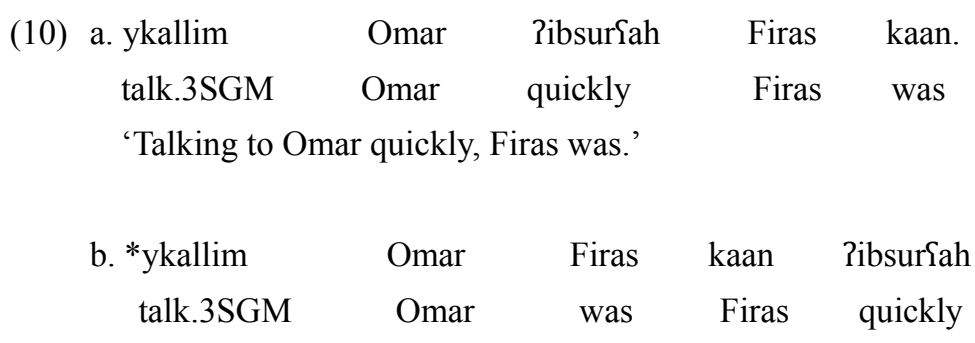

Intended: 'Talking to Omar quickly, Firas was.'

Against this background, two questions arise: (Note 3)

1) Why does L-verb fronting in NHA require pied-piping of the DO and any other accompanying adjunct? 
2) Why does DO fronting not require L-verb or adjunct fronting?

In the next section, these two questions are approached within the recent assumptions and advancements of the Minimalist Program (Chomsky, 1995 and subsequent work).

\section{Discussion}

Following current generative practice, it can be advanced that when L-verb does not move to adjoin $\mathrm{T}^{\mathrm{o}}$, it remains in situ in sentences with unaccusative predicates. In case of sentences with unergative or transitive predicates (the main concern of the current research), L-verb remains adjoining little affixal $\mathrm{v}^{\mathrm{o}}$ (cf. Hale \& Keyser, 1993; Chomsky, 1995). Additionally, following Chomsky (2007), we assume that the DO vacates its base position to the Spec of VP. However, such a movement is masked by the concurrent movement of L-verb to $\mathrm{v}^{\mathrm{o}}$. Consider the following syntactic derivation of sentence (1d), reproduced below in (11) (silent copies were crossed out and irrelevant details were ignored):

$\begin{array}{rllll}\text { (11) Firas } & \text { kaan } & \text { ykallim } & \text { Omar } & \text { 2ibsurfah. } \\ \text { Firas } & \text { was } & \text { talk.3SGM } & \text { Omar } & \text { quickly }\end{array}$

'Firas was talking to Omar quickly.'

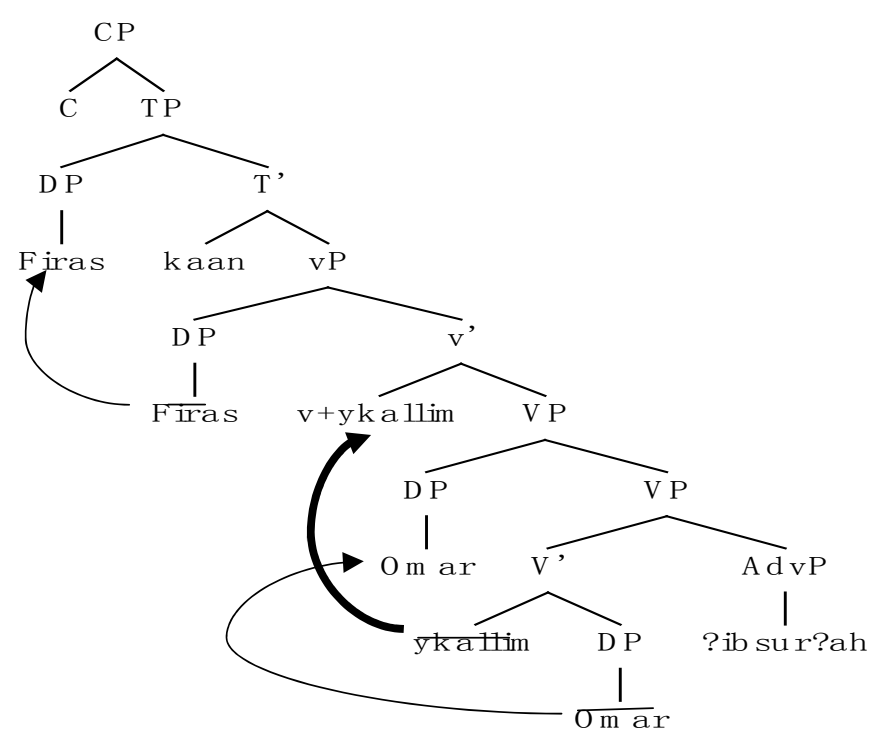

The derivation in (12) accounts for most of cases with overt tense. L-verb adjoins $\mathrm{v}^{0}$ being affixal in nature, while the DO occupies Spec of VP headed by L-verb. Any adjunct like Ribsur Fah 'quickly' seems to adjoin the maximal projection of VP. When an adjunct appears between $\mathrm{T}^{\mathrm{o}}$ and L-verb, it is assumed to merge with vP rather than VP, as in sentence (4) repeated below in (13):
(13) Firas
kaan Ribsurfah
ykallim
Omar.
Firas
was quickly
talk.3SGM
Omar

'Firas was talking to Omar quickly.' 
(14)

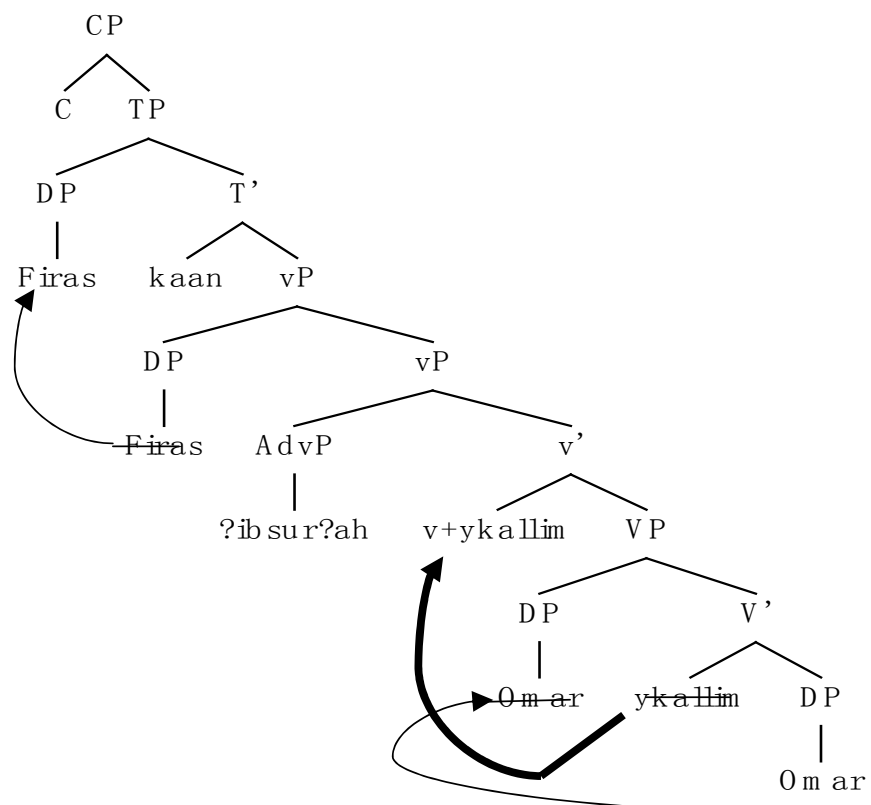

As referred to above, L-verb can be fronted if tied to an appropriate pragmatic context. According to the first researcher's intuition and NHA informants we consulted, L-verb fronting is viewed as a subcase of topicalization given that the subject precedes kaan. When the subject follows kaan, L-verb fronting does not demand a topicalization reading. Consider the contrast: (Note 4)

(15)
a. ykallim
Omar
Firas kaan.
talk.3SGM
Omar
Firas
was

'Talking to Omar, Firas was.'

$\begin{array}{lllll}\text { b. ykallim } & \text { Omar } & \text { kaan } & \text { radzaal } & \text { barra. } \\ \text { talk.3SGM } & \text { Omar } & \text { was } & \text { man } & \text { outside }\end{array}$

'A man was talking to Omar outdoors.'

The intricate not trivial difference between sentences in (15) and the relation of the subject position to L-verb fronting is however beyond the bounds of the current research. What need concern us here is that L-verb pied-pipes the DO in both cases and does not move on its own.

$$
\begin{array}{cccc}
\text { (16) a.* ykallim } & \text { Firas } & \text { kaan } & \text { Omar. } \\
\text { talk.3SGM } & \text { Firas } & \text { was } & \text { Omar }
\end{array}
$$

Intended: 'Talking to Omar, Firas was.'

$\begin{array}{ccccc}\text { b. *ykallim } & \text { kaan } & \text { radzaal } & \text { barra } & \text { Omar. } \\ \text { talk.3SGM } & \text { was } & \text { man } & \text { outside } & \text { Omar }\end{array}$

Intended: 'A man was talking to Omar outdoors.'

$\begin{array}{lrccc}\text { c. *ykallim } & \text { kaan } & \text { radzaal } & \text { Omar } & \text { barra. } \\ \text { talk.3SGM } & \text { was } & \text { man } & \text { Omar } & \text { outside }\end{array}$

Intended: 'A man was talking to Omar outdoors.' 
One possibility for this is that no topicalization is available for L-verb alone in NHA. This possibility comes, indeed, naturally. Keep the second case where L-verb fronting does not demand topicalization aside, L-verb topicalization is used when the speaker topicalizes the event rather than the semantic content of L-verb (cf. Källgren \& Prince, 1989; Diesing, 1990; Krifka, 1998; among others). L-verb alone does not represent the whole action but, by definition, part of it. The DO being pied-piped with the L-verb increases the elements participating in the event, and hence, makes verb topicalization conceptually acceptable. In relation to this, we argue that the least acceptable amount of information to be licensed as 'event topicalization' is L-verb + the DO, if intransitive predicates kept aside. This type of event topicalization is labelled, for lack of a better term, as Defective Predicate Topicalization (henceforth, DPT). Defection comes from the lack of tense rather than the lack of the subject inasmuch as the latter is not part of the predicate. The subject is originally what predication is about (Rizzi, 2007; Rizzi \& Shlonsky, 2006, 2007). Hence, DPT must not include the subject, an issue confirmed by L-verb and DP fronting (see 15a).

The immediate question bearing consideration at this point is how such facts on DPT can be syntactically derived. Put differently, can the movement of L-verb alongside the DO be reduced to some syntactic principle? In order to answer this question, we appeal to locality constraints on derivation and movement (Note 5). As a first approximation, L-verb movement alone to the dedicated topic projection in the left periphery incurs a violation of locality. Such violation is caused by intervention effects caused by overt $\mathrm{T}^{\mathrm{o}}$. Consider the representation of sentence (16a) in (17) below:

(17) * ykallim

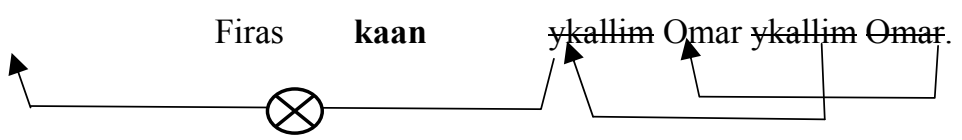

L-verb movement to the left periphery is barred due to the presence of an intervening head, i.e., $\mathrm{T}^{\mathrm{o}}$, en route. For $\mathrm{L}$-verb to move to the left periphery (or even any position atop $\mathrm{T}^{\circ}$ ), it must first skip over $\mathrm{T}^{\mathrm{o}}$. However, in cases where $\mathrm{T}^{\mathrm{o}}$ is overtly filled by a free morpheme like kaan, there is no way for $\mathrm{L}$-verb to get preposed due to the intervention effect caused by T ${ }^{\mathrm{o}}$ (cf. Kim, 2002; Beck, 2006; Tomioka, 2007; Choi, 2007; Friedmann et al., 2009). In cases where there is no overt tense, L-verb (or in fact the amalgamated L-verb + little $\mathrm{v}^{\circ}$ ) moves to $\mathrm{T}^{\mathrm{o}}$, then the amalgamated head (L-verb + little $\mathrm{v}^{\mathbf{0}}+$ tense) moves to the left periphery, given that there are no heads inducing any intervention effect. See the following sentence where L-verb gets preposed without the DO:

(18)

$\begin{array}{llll}\text { ykallim } & \text { Firas } & \text { Omar } & \text { Ribsurfah. } \\ \text { talk.3SGM } & \text { Firas } & \text { Omar } & \text { quickly }\end{array}$

'Firas is talking to Omar quickly.'

The amalgamated head ( $\mathrm{L}-\mathrm{verb}+$ little $\mathrm{v}^{\mathrm{o}}$ ) adjoins $\mathrm{T}^{\mathrm{o}}$ as far as sentence (18) is concerned. If DPT is intended (as in 19), the DO must be pied-piped along L-verb movement. Here the possibility that all of the amalgamated head $\left(\mathrm{L}\right.$-verb + little $\left.\mathrm{v}^{\circ}\right)$ and the DO move to null $\mathrm{T}^{\circ}$ and then to the left periphery, as in sentence (19), is untenable.

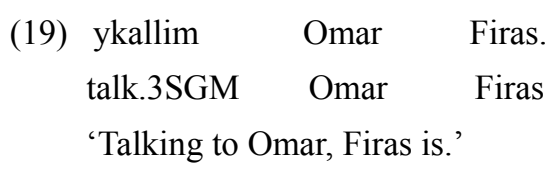

The DO cannot move as part of the amalgamated head (L-verb + little $\mathrm{v}^{\mathrm{o}}$ ) to $\mathrm{T}^{\mathrm{o}}$ for its sharp violation for sentence derivation principles and structure preservation rules (cf. Myers, 1991; Itô \& Mester, 1993; Chomsky, 1995, 2008 among others). Indeed, we cast doubt on the suggested correlation obtained between whether $\mathrm{T}^{\mathrm{o}}$ is overtly filled or not and the movement of the DO along with L-verb to the left periphery. In either way, DPT is available. Therefore, how DPT (L-verb + the DO) is licensed in syntax? The answer to this question lies, we assume, in the type of movement both L-verb and the DO undergo. Because DPT demands movement of L-verb in addition to the DO, what moves is the whole vP as a phrasal movement. This is tantamount to the assumption that L-verb and the DO move to the left periphery at one fell swoop. Consider the schematic representation of 
sentence (7a) repeated below for convenience.

(20)

$\begin{array}{llll}\text { ykallim } & \text { Omar } & \text { Firas } & \text { kaan. } \\ \text { talk.3SGM } & \text { Omar } & \text { Firas } & \text { was }\end{array}$

'Talking to Omar, Firas was.'

(21)

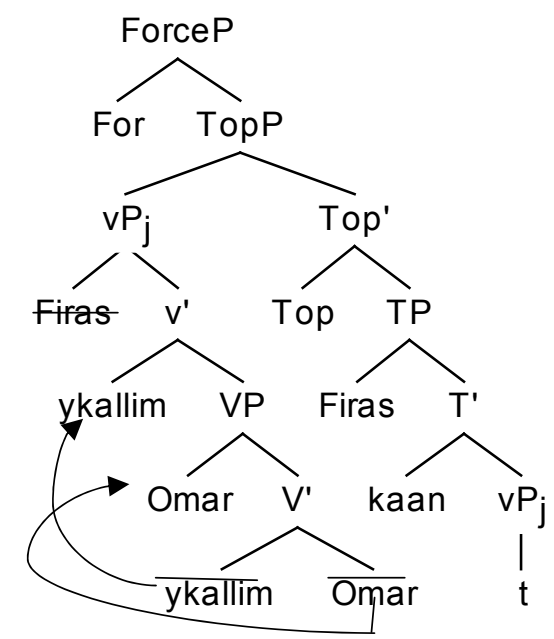

What happens here is that the whole vP moves to the left periphery (i.e., Spec of TopicP). In this light, DPT can be a phase-phrasal movement in the sense of Chomsky (2008). That is because the whole lower phase $\mathrm{v}^{*} \mathrm{P}$ moves. Additionally, adopting this approach, the linear order between L-verb and the DO straightforwardly follows. The latter must follow the former. Before moving to the dedicated topic projection in the left periphery, L-verb c-commands the DO even though both do not reside in their first-merged positions. As shown above, L-verb in Arabic (and in most languages, following Chomsky, 2007) adjoins the little $\mathrm{v}^{\circ}$, while the DO moves to the Spec of VP, hence, the position of L-verb to the left of the DO. Once L-verb and the DO move to the left periphery as one bloc, they maintain the same order they used to have prior to their movement, hence, again, the L-verb precedence to the DO. Such a linear relation between L-verb and the DO can be taken as convergent evidence for the phrasal movement the current research advocates for DPT in NHA. If the character of the movement is not phrasal, thus, why the DO is barred to appear before L-verb after movement (e.g., no DO focalization).
(22)* Omar ykallim Firas kaan.
Omar talk.3SGM Firas was
Intended: 'Talking to Omar, Firas was.'

In line with our thesis, the DO moves along the L-verb (pied-piped) in the same order they appear before movement (see the schematic derivation in (14) above). According to recent practice on movement and chain construction (Hornstein, 1999, Embick \& Noyer, 2001; Bošković, 2002; Adger \& Svenonius, 2011), there is no way to move or even extract the DO from an already moved vP (or any other syntactic projection/object), thereby the ungrammaticality of sentence (22). Therefore, the claim made by Gallego and Uriagereka (2007) that no elements are allowed to move out of an already moved projection is on the right track as far as NHA is concerned.

Furthermore, phrasal movement approach accounts for mandatory movement of any adjunct along L-verb and the Do. As referred to above, the adjunct either precedes L-verb or follows the DO. At any rate, adjuncts cannot intervene between L-verb and the DO. Consider the following sentence: 


$\begin{array}{lcccc}\text { (23) a. ykallim } & \text { Omar } & \text { Ribsurfah } & \text { Firas } & \text { kaan. } \\ \text { talk.3SGM } & \text { Omar } & \text { quickly } & \text { Firas } & \text { was }\end{array}$

'Firas was talking to Omar quickly.'

$\begin{array}{cllll}\text { b. Pibsurfah } & \text { ykallim } & \text { Omar } & \text { Firas } & \text { kaan. } \\ \text { quickly } & \text { talk.3SGM } & \text { Omar } & \text { Firas } & \text { was }\end{array}$

'Firas was talking to Omar quickly.'

$\begin{array}{lllll}\text { c. *ykallim } & \text { 2ibsurfah } & \text { Omar } & \text { Firas } & \text { kaan. } \\ \text { talk.3SGM } & \text { quickly } & \text { Omar } & \text { Firas } & \text { was }\end{array}$

Intended: 'Firas was talking to Omar quickly.'

The grammaticality of $(23 a, b)$ and the ungrammaticality of (23c) can be neatly accounted for, following our account. The order maintained between L-verb, the DO and the adjunct in the left periphery is the same linear order respected between them before displacement. Following this line of thought, we argue that sentence (23a) is the base sentence for (24a), while (23b) is that of (24b).

(24)
a. Firas
kaan ykallim
Omar
Pibsurfah.
Firas
was
talk.3SGM
Omar
quickly

'Talking to Omar quickly, Firas was.'

$\begin{array}{rrrll}\text { b. Firas } & \text { kaan } & \text { Pibsurfah } & \text { ykallim } & \text { Omar. } \\ \text { Firas } & \text { was } & \text { quickly } & \text { talk.3SGM } & \text { Omar }\end{array}$

'Talking to Omar quickly, Firas was.'

Consider the schematic representation for both (23a) and (23b) in (25a) and (25b), respectively:

(25)a.

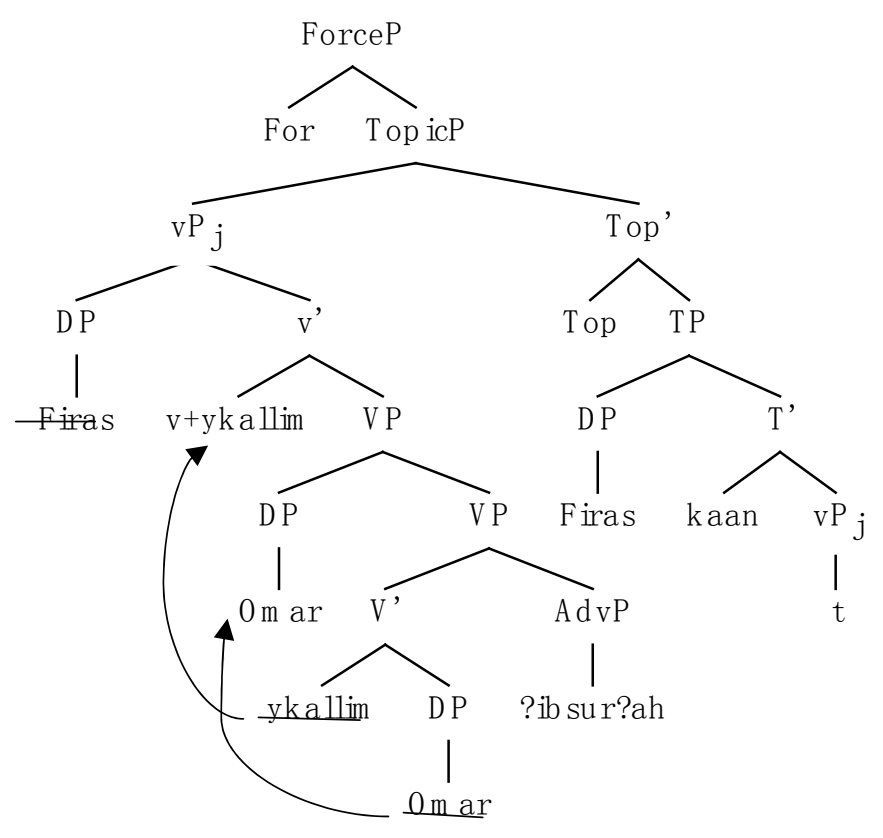


b.

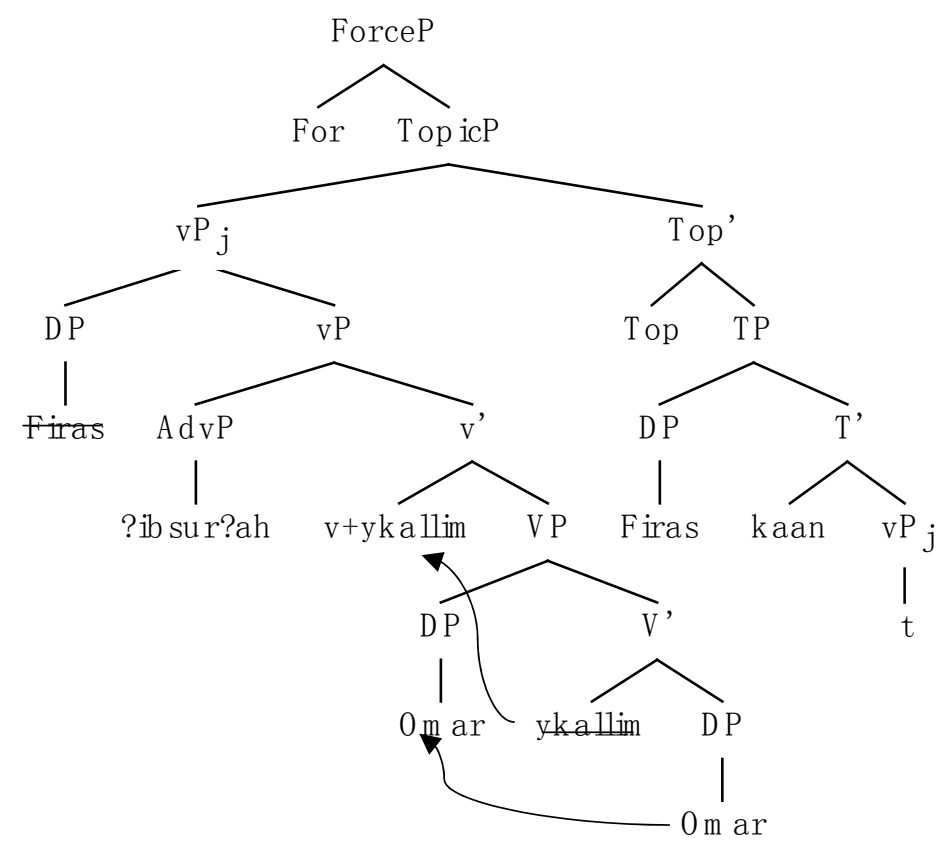

Saying this, it appears that adjuncts of the lower phase $\mathrm{v}^{*} \mathrm{P}$ either adjoin the lower VP as right adjunction, or adjoin the upper $\mathrm{vP}$ as left adjunction. No left adjunction to VP is possible in the grammar of NHA, hence, ill-formedness of sentences such (23c) where the adjunct intervenes between L-verb and the DO.

Besides, the subject position to the right of the whole displaced phase entails subject movement to Spec of TP. However, the copy of the subject is part of the moved bloc. This assumption rests crucially on cross-linguistic evidence that intermediate levels, like V', cannot move, given their invisibility to grammar; see, Rizzi's (2015: 327) Maximality Principle. What moves is either a zero level category $\left(\mathrm{X}_{0}\right)$ or a maximal projection (XP).

Now with this analysis, let us consider the second main question posed earlier. The DO movement to the left periphery as in sentence (8), repeated below in (26) for ease of exposition, does not demand the L-verb to get pied-piped along the moved DO.

$\begin{array}{rrrl}\text { (26) Omar } & \text { Firas } & \text { kaan } & \text { ykallim-uh. } \\ \text { Omar } & \text { Firas } & \text { was } & \text { talk.3SGM-3SGM }\end{array}$

'Omar, Firas was talking to him.'

Following our pursuit, the DO is still available for extraction since it is not included in a projection (or a phase) already moved. In addition, DO movement does not induce violations to any head-related locality principles since it is simply not a zero-level category that heads a maximal projection. Thus, the way to the left periphery is, in principle, still open.

\section{Conclusion}

In this research, some aspects of verb topicalization were investigated in NHA. The main argument advanced was that L-verb+DO topicalization, labelled as DPT, is possible in this dialect. DPT operates as follows. L-verb moves to little $\mathrm{v}^{\mathrm{o}}$, while the DO moves to Spec of VP. Then, the amalgamated head (L-verb + little verb) moves to a dedicated Topic Phrase in the left periphery, pied-piping all the material adjoining it (the DO and any adjunct). DPT is thus a manifestation of phrasal movement, not incurring any violation to locality or sentence derivation principles and constraints. Additionally, the current paper corroborated that movement out of an already moved projection is barred. DO focalization or extraction is no longer possible if case it is part of DPT. As indicated, this analysis yields no pains to current syntactic theory but indeed in harmony with it. However, some other issues remain open for future research, including L-verb movement along the DO to the left of $\mathrm{T}^{\mathrm{o}}$ 
without demanding discourse-bound reading. It seems that such a movement is motivated by a different mechanism vis-à-vis DPT, say, satisfying the EPP. (Notes 6 and 7)

\section{References}

Ackema, P., \& Neeleman, A. (2012). Agreement weakening at PF: A reply to Benmamoun and Lorimor. Linguistic inquiry, 43, 75-96. http://dx.doi.org/10.1162/LING_a_00074

Adger, D., \& Svenonius, P. (2011). Features in minimalist syntax. The Oxford handbook of linguistic minimalism, 27-51. http://dx.doi.org/10.1093/oxfordhb/9780199549368.013.0002

Alhaisoni, E., Jarrah, M. A., \& Shehadeh, M. S. (2012). An investigation of evidentiality in the Arabic language. International Journal of Linguistics, 4(2), pp-260.

Al-Jarrah, R. S., Abu Dalu, A. M., \& Jarrah, M. (2015). A Relevance-Theoretical Account of Three Arabic Pragmatic Operators of Concession in a Political Discourse. Lodz Papers in Pragmatics, 11, 51-76. http://dx.doi.org/10.1515/lpp-2015-0004

Alrasheedi, E. S. (2015). Affrication in Ha'ili Arabic: A Rule-Based Approach. International Journal of Linguistics, 7, 27-41. http://dx.doi.org/10.5296/ijl.v7i4.8017

Alshamari, M. (2015c). Documentation of discourse-related Particles in North Hail Arabic. English Linguistics Research, 4, 44-57. http://dx.doi.org/10.5430/elr.v4n4p44

Al-Shamari, M. R. (2015a). Pragmatic Analysis of the Particle sadı in Najdi Arabic. International Journal of Linguistics, 7, 81-93.

Alshamari, M. R. (2015b). A Relevance-Theoretical Account of Three Discourse Markers in North Hail Arabic. Studies in Literature and Language, 11, 6-15.

Aoun, J., Benmamoun, E., \& Choueiri, L. (2010). Arabic syntax. Cambridge: Cambridge.

Beck, S. (2006). Intervention effects follow from focus interpretation. Natural Language Semantics, 14, 1-56. http://dx.doi.org/10.1007/s11050-005-4532-y

Benmamoun, E. (1999). Arabic morphology: The central role of the imperfective. Lingua, 108, 175-201. http://dx.doi.org/10.1016/S0024-3841(98)00045-X

Benmamoun, E. (2000). The feature structure of functional categories: A comparative study of Arabic dialects (Vol. 16). Oxford University Press.

Bentzen, K. (2014). Verb placement in relative clauses. Nordic Atlas of Language Structure, 1, 240-249.

Biberauer, T., \& Roberts, I. (2009). Subjects, Tense and verb-movement. Parametric variation: Null subjects in minimalist theory, 263.

Biberauer, T., Holmberg, A., Roberts, I., \& Sheehan, M. (2009). Parametric variation: Null subjects in minimalist theory. Cambridge University Press. http://dx.doi.org/10.1017/cbo9780511770784

Bolotin, N. (1995). Arabic and parametric VSO agreement. Amsterdam Studies in The Theory And History Of Linguistic Science Series, 4, 7-7. http://dx.doi.org/10.1075/cilt.130.04bol

Bošković, Ž. (2002). A-movement and the EPP. Syntax, 5, 167-218. http://dx.doi.org/10.1111/1467-9612.00051

Choi, Y. S. (2007). Intervention effect in Korean wh-questions: Indefinite and beyond. Lingua, 117, 2055-2076. http://dx.doi.org/10.1016/j.lingua.2007.01.001

Chomsky, N. (1995). The minimalist program. Cambridge, MA: MIT press.

Chomsky, N. (2007). Approaching UG from below. Interfaces + recursion=language, 89, 1-30.

Chomsky, N. (2008). On phases. Current Studies in Linguistics Series, 45, 133. http://dx.doi.org/10.7551/mitpress/9780262062787.003.0007

Diesing, M. (1990). Verb movement and the subject position in Yiddish. Natural Language and Linguistic Theory, 8, 41-79. http://dx.doi.org/10.1007/bf00205531

Embick, D., \& Noyer, R. (2001). Movement operations after syntax. Linguistic inquiry, 32, 555-595. http://dx.doi.org/10.1162/002438901753373005

Fassi Fehri, A. (2012). Key features and parameters in Arabic grammar (Vol. 182). John Benjamins Publishing. http://dx.doi.org/10.1075/la.182

Fassi Fehri, A. (2013). Issues in the structure of Arabic clauses and words (Vol. 29). Springer Science and 
Business Media.

Friedmann, N., Belletti, A., \& Rizzi, L. (2009). Relativized relatives: Types of intervention in the acquisition of A-bar dependencies. Lingua, 119, 67-88. http://dx.doi.org/10.1016/j.lingua.2008.09.002

Gallego, Á. J., \& Uriagereka, J. (2007). Conditions on sub-extraction. In L. Eguren \& O. Fernández-Soriano (Eds.), Coreference, modality, and focus (pp. 45-70). http://dx.doi.org/10.1075/la.111.04gal

Haeberli, E., \& Pintzuk, S. (2012). Revisiting verb (projection) raising in Old English. Grammatical change: origins, nature, outcomes, 219.

Hale, K., \& Keyser, S. J. (1993). On argument structure and the lexical expression of syntactic relations. The view from Building, 20, 53-109.

Hornstein, N. (1999). Movement and control. Linguistic inquiry, 30, 69-96. http://dx.doi.org/10.1162/002438999553968

Itô, J., \& Mester, A. (1993). Japanese phonology: constraint domains and structure preservation. The handbook of phonological theory, 817-838.

Jarrah, M. A. (2016). Explicit-implicit Distinction: A Literature Review. Advances in Language and Literary Studies, 7, 175-184.

Källgren, G., \& Prince, E. F. (1989). Swedish VP-topicalization and Yiddish verb-topicalization. Nordic Journal of Linguistics, 12, 47-58. http://dx.doi.org/10.1017/S033258650000192X

Kenstowicz, M. (1989). The Null Subject Parameter in Modern Arabic Dialects. In O. Jaeggli \& K. Safir (Eds.), The Null Subject Parameter (pp. 263-276). Kluwer, Dordrect. http://dx.doi.org/10.1007/978-94-009-2540-3_9

Kim, S. S. (2002). Focus matters: Two types of intervention effect. WCCFL XXI.

Kinberg, N. (1992). Semi-imperfectives and imperfectives: a case study of aspect and tense in Arabic participial clauses. Lingua, 86, 301-330. http://dx.doi.org/10.1016/0024-3841(92)90066-R

Koeneman, O. (2000). The flexible nature of verb movement. Doctoral dissertation, Netherlands Graduate School of Linguistics.

Koeneman, O., \& Zeijlstra, H. (2014). The rich agreement hypothesis rehabilitated. Linguistic Inquiry, 45(4), 571-615. http://dx.doi.org/10.1162/LING_a_00167

Kremers, J. (2012). Arabic Verbal Nouns as Phonological Head Movement. In G. Iordăchioaia (Ed.), Proceedings of JeNom 4. (Vol. 9). Working Papers of the SFB 732 Incremental Specification in Context. Stuttgart University, pp. 73-96.

Krifka, M. (1998). Scope inversion under the rise-fall contour in German. Linguistic Inquiry, 29, 75-112. http://dx.doi.org/10.1162/002438998553662

Lasnik, H. (1995). Case and expletives revisited: On Greed and other human failings. Linguistic inquiry, 26(4), 615-633.

Lewis, R. (2013). Complementizer Agreement in Najdi Arabic (Doctoral dissertation, University of Kansas).

Myers, S. (1991). Structure preservation and the strong domain hypothesis. Linguistic Inquiry, 22(2), 379-385.

Ouhalla, J. (1994). 2 Verb movement and word order in Arabic. Verb movement, 41. http://dx.doi.org/10.1017/CBO9780511627705.004

Ouhalla, J., \& Shlonsky, U. (2002). Themes in Arabic and Hebrew Syntax. Kluwer, Dordrecht. http://dx.doi.org/10.1007/978-94-010-0351-3

Owens, J. (Ed.). (2013). The Oxford handbook of Arabic linguistics. Oxford University Press. http://dx.doi.org/10.1093/oxfordhb/9780199764136.001.0001

Palmer, F. R. (2001). Mood and modality. Cambridge University Press. http://dx.doi.org/10.1017/cbo9781139167178

Rizzi, L. (1990). Relativized minimality. The MIT Press.

Rizzi, L. (1997). The Fine Structure of the Left Periphery. In L. Haegeman (Ed.), Elements of Grammar (pp. 281-337). Kluwer, Dordrecht. http://dx.doi.org/10.1007/978-94-011-5420-8_7

Rizzi, L. (2007). On some properties of criterial freezing. Studies in linguistics, 1, 145-158. 
Rizzi, L. (2015). Cartography, criteria, and labelling. Beyond Functional Sequence: The Cartography of Syntactic Structures, 10, 314.

Rizzi, L., \& Shlonsky, U. (2006). Satisfying the subject criterion by a non-subject: English locative inversion and Heavy NP shift. Phases of interpretation, 341-361. http://dx.doi.org/10.1515/9783110197723.5.341

Rizzi, L., \& Shlonsky, U. (2007). Strategies of subject extraction. Interfaces + recursion= language, 115-160.

Roberts, I. G. (2005). Principles and parameters in a VSO language: A case study in Welsh. Oxford: Oxford University Press. http://dx.doi.org/10.1093/acprof:oso/9780195168211.001.0001

Roberts, I. G. (2007). Diachronic syntax. Oxford University Press, USA.

Saiegh-Haddad, E., \& Henkin-Roitfarb, R. (2014). The structure of Arabic language and orthography. In Handbook of Arabic Literacy (pp. 3-28). Springer Netherlands. http://dx.doi.org/10.1007/978-94-017-8545-7_1

Schub, M. B. (1977). Focusing and Topicalization in Classical Arabic. Arabica, 207-210. http://dx.doi.org/10.1163/157005877X00064

Shlonsky, Ur. (1997). Clause Structure and Word Order in Hebrew and Arabic: An Essay in Comparative Semitic Syntax. New York: Oxford University Press.

Soricut, R., \& Marcu, D. (2003, May). Sentence level discourse parsing using syntactic and lexical information. In Proceedings of the 2003 Conference of the North American Chapter of the Association for Computational Linguistics on Human Language Technology-Volume 1 (pp. 149-156). Association for Computational Linguistics. http://dx.doi.org/10.3115/1073445.1073475

Taha, K. T., Jarrah, M. A., \& Al-Jarrah, R. S. (2014). The Discoursal Arabic Coordinating Conjunction Wa (And). International Journal of Linguistics, 6, 172. http://dx.doi.org/10.5296/ijl.v6i4.4547

Tomioka, S. (2007). Pragmatics of LF intervention effects: Japanese and Korean wh-interrogatives. Journal of Pragmatics, 39, 1570-1590. http://dx.doi.org/10.1016/j.pragma.2007.03.002

Travis, L. (1984). Parameters and effects of word order variation. Doctoral dissertation, MIT, Cambridge, Mass.

Truckenbrodt, H. (2006). On the semantic motivation of syntactic verb movement to $\mathrm{C}$ in German. Theoretical Linguistics, 32, 257-306. http://dx.doi.org/10.1515/TL.2006.018

Tucker, M. A. (2011). The morpho-syntax of the Arabic verb: Toward a unified syntax-prosody. Linguistics Research Centre.

\section{Notes}

Note 1. See Palmer (2001) for a fuller explanation of the relation between tense and modality.

Note 2. See Alhaisoni et al. (2012) for special cases where some tense clashes are tolerable. However, as unequivocally seen from this paper, tense clashes are tolerable in special texts, including the Glorious Quran, serving some evidential function.

Note 3. What we mean precisely by verb movement is the movement of L-verb to the left periphery without landing en route in $\mathrm{T}^{\circ}$.

Note 4. It should be noted that sentences in (15) are marked cases of word order in NHA. So, markedness of such structures forces the speaker and the hearer to exert more effort to process the given sentence (cf. Taha et al., 2014; Alshamari, 2015a; Al-Jarrah et al., 2015; Jarrah, 2016).

Note 5. Current Minimalist locality constraints are based originally on Rizzi's (1990) Relativized Minimality and Travis's (1984) head movement constraint (HMC).

Note 6. What is special about sentence (15b) is the whole vP moved to some position before $\mathrm{T}^{\mathrm{o}}$. However, no topicalization or focalization for the event is intended or adduced in the interpretation. It is not viewed a case of DPT for all of the informants consulted.

Note 7. Both researchers are indebted to all NHA informants who shared with us their intuition. 


\section{Copyrights}

Copyright for this article is retained by the author(s), with first publication rights granted to the journal.

This is an open-access article distributed under the terms and conditions of the Creative Commons Attribution license (http://creativecommons.org/licenses/by/3.0/). 